\title{
Model Numerik Sebaran Sedimen Tersuspensi di Muara Sungai Pulege Kabupaten Donggala
}

\author{
Maryam, Yutdam Mudin, Abd. Rahman \\ Jurusan Fisika Fakultas Matematika Dan Ilmu Pengetahuan Alam
}

\begin{abstract}
ABSTRAK
Sungai Pulege memiliki peran penting sebagai penyalur material tersuspensi dari daerah hulu menuju laut. Proses sebaran sedimen di perairan laut dipengaruhi oleh faktor fisika oseonografi. Tujuan dari penelitian ini adalah memodelkan pola sedimen tersuspensi untuk menentukan sebaran konsentrasinya di muara Sungai Pulege. Dalam penelitian meliputi data primer berupa kosentrasi sedimen tersuspensi, dan debit sungai sedangkan data sekunder berupa peta batimetri, RBI, data pasut, arus dan angin. Penelitian menggunakan metode kuantitatif, analisis sampel sedimen tersuspensi menggunakan metode Gravimetri di laboratorium FMIPA UNTAD dan pembuatan model sebaran konsentrasi sedimen tersuspensi menggunakan pendekatan matematik SED2D dalam Software Surface Water Modelling System (SMS). Hasil penelitian dengan menggunakan modul SED2D menunjukkan bahwa nilai konsentrasi maksimum sedimen tersuspensi yang berada di sekitaran sungai khusususnya di stasiun I sebesar 0.40 gram/liter, dan menyebar kearah sekitaran Perairan Pantai Tanamea khususnya pada stasiun II sebesar 0.03 gram/liter. Nilai debit Sungai Pulege pada saat pengukuran sebesar $14.37 \mathrm{~m}^{3} / \mathrm{det}$. Arus dominan disekitaran Perairan Pantai Tanamea adalah arus pasut, dan kecepatan arus maksimum $0.27 \mathrm{~m}^{3} /$ det. Dari hasil penelitian dapat disimpulkan bahwa nilai konsentrasi sedimen tersuspensi terbesar berada didaerah sungai dan mengecil ketika menuju laut. Hal ini mengakibatkan di daerah muara sungai tidak terjadi pendangkalan dan tidak dapat mengganggu ekosistem, biota laut sekitaran Pantai Tanamea. Hasil penelitian yang diperoleh dapat disimpulkan bahwa sebaran sedimen tarsuspensi di wilayah yang dikaji sangat dipengaruhi oleh arus pasang surut, dan pada Stasiun II arah sebaran sedimen tersuspensi dominan ke barat laut.
\end{abstract}

Kata kunci : Sedimen tersuspensi, Debit Sungai, SED2D, Perairan Selat Makassar 


\begin{abstract}
The research on the numerical model of the distribution of suspended sediments was carried out with the object Sungai Pulege, South Banawa, Donggala Regency. The purpose of this research was to model suspended sediment patterns to determine the distribution of concentrations in the Pulege River estuary. In the study used primary data in the form of suspended sediment concentration, and river discharge while secondary data used bathymetry maps, RBI map, tidal data, currents and wind. The study used a quantitative method, analysis of suspended sediment samples using the gravimetric method and the making of a suspended sediment concentration distribution model using the SED2D mathematical approach in the Surface Water Modeling System (SMS) Software. The results of the study using the SED2D module showed that the maximum concentration value of suspended sediments in the vicinity of the river (station I) was 0.40 gram/liter and spread towards the coast waters of Tanamea (station II) of 0.03 grams/liter. The Pulege River discharge value at the time of measurement is $14.37 \mathrm{~m}^{3} / \mathrm{sec}$. The dominant current in the coastal waters of Tanamea was tidal currents with a maximum current velocity of $0.27 \mathrm{~m}^{3} / \mathrm{sec}$. From the results of the study it can be concluded that the largest suspended sediment concentration values were in the river area and shrink when heading to the sea. This process resulted in no river silting in the estuary area and could not disturb the ecosystem, marine biota around Tanamea Beach.
\end{abstract}

Keywords: Suspended sediments, River discharge, SED2D 


\section{I.PENDAHULUAN}

Muara sungai merupakan bagian hilir sungai yang berhubungan langsung dengan laut. Salah satu fungsi dari muara sungai yaitu sebagai penyalur debit sungai dari darat ke laut terutama pada waktu banjir (Triatmodjo, 1999). Sungai menjadi media berlangsungnya proses morfologi, baik berupa erosi, transportasi maupun sedimnetasi. Salah satu proses yang terjadi melalui sungai adalah proses transportasi sedimen. Sedimen dapat mengalami transportasi melalui tiga mekanisme yaitu sebagai muatan sedimen terlarut, muatan sedimen melayang (sedimen suspense) dan muatan sedimen dasar (Soewarno, 1991). Semakin besar debit aliran sungai maka semakin banyak pula sedimen suspensi yang akan terangkut dari hulu ke muara dan menyebar di sekitar muara. Sungai Pulege adalah sungai utama di DAS (daerah aliran sungai) Tanamea. Sungai ini termasuk sungai besar dan permanen (berair sepanjang tahun), yang bermuara di perairan pantai Tanamea. Muara tersebut sekaligus sebagai batas alam antara Desa Tanamea dan Desa Lembasada di Kecamatan Banawa Selatan Kabupaten Donggala.
Secara geografis pantai Desa Tanamea, berbatasan dengan perairan Selat Makassar dan berada pada posisi119 $9^{\circ}$ 37' $05^{\prime \prime}$ - $119^{\circ} 38^{\prime} 05^{\prime \prime}$ BT dan $0^{\circ} 47^{\prime} 45^{\prime \prime}$ $0^{\circ} 48^{\prime} 48^{\prime \prime}$ LS. DAS Tanamea berupa pegunungan dan perbukitan yang banyak ditumbuhi pepohanan dan perkebunan masyarakat yang memberikan sumbangsih pada aliran sedimen pada badan sungai. Dengan kondisi ini menyebabkan terjadinya kekeruhan pada badan sungai yang terindikasi oleh konsentrasi TSS (total suspended solid). Pantai Desa Tanamea juga merupakan salah satu pantai tempat wisata di Kabupaten Donggala yang sebagian besar masyarakatnya bermata pencaharian nelayan. Dengan kondisi pantai tersebut maka perlu diadakan penelitian mengenai tingkat kekeruhan air yang disebabkan oleh tingkat konsentrasi TSS agar dapat diketahui bagaimana keseimbangan ekositim dan kondisi biota laut yang ada di perairan tersebut.

Fenomena fisis dan dinamis yang terjadi di wilayah pesisir Pantai Tanamea adalah gerak naik turunnya permukaan air laut secara periodik yang dipengaruhi oleh benda-benda langit. Perubahan permukaan laut yang periodik itu disebut dengan 
istilah gelombang pasang surut. Gelombang pasang surut ini akan menghasilkan arus pasang surut yang berubah arah dan kecepatannya berdasarkan pasang dan surutnya permukaan air. Arus pasang surut dan debit sungai merupakan faktor utama yang membawa perubahan terhadap kondisi konsentrasi sedimen tersuspensi di muara dan perairan sekitarnya.

Potensi terjadinya sedimentasi dapat diketahui dengan menentukan besar konsentrasi sedimen tersuspensi di daerah tersebut. Aliran Sungai Pulege merupakan media pemasok sedimen menuju Pantai Tanamea. Debit sungai mengangkut sedimen tersuspensi di sungai dan ketika menuju laut dipengaruhi oleh arus akibat pasang surut. Poerbandono dan Djunarsjah (2005) menyatakan bahwa sedimen yang berukuran lebih kecil cenderung terangkut sebagai suspensi yang mengikuti kecepatan dan arah arus. Sehingga perlu dikaji konsentrasi dan sebaran sedimen tersuspensi di Pantai Tanamea.

Adanya permasalahan serius yang ditimbulkan oleh faktor sedimen tersuspensi, maka telah banyak dilakukan penelitian mengenai sebaran sedimen tersuspensi yang di arahkan untuk menyediakan data-data aktual mengenai kondisi fisik suatu perairan. Penelitian mengenai sedimen tersuspensi, sudah di lakukan oleh Sinaga dkk (2013), yang melakukan pemodelan sebaran sedimen tersuspensi berdasarkan model pola arus dan pasang surut di perairan Teluk Balikpapan dengan menggunakan metode Software Mike 21 Flexible Mesh Mud Transport. dengan mendapatkan nilai konsentrasi sedimen tersuspensi terbesar pada saat pasang purnama berkisar antara $0.016 \mathrm{~kg} / \mathrm{m}^{3}-0.024 \mathrm{~kg} / \mathrm{m} 3$. Kemudian Damayanti dan Hernawan (2014) serta Atmodjo (2011), melakukan studi dan pemodelan pola penyebaran sedimen tersuspensi berdasarkan analisis debit maksimum dan minimum di muara Sungai Porong. Dengan mendapatkan hasil simulasi sebaran konsentrasi sedimen tersuspensi selama 15 hari berkisar antara $3.803 \mathrm{mg} / \mathrm{liter}-240.448 \mathrm{mg} / \mathrm{liter}$. Penelitian ini sampai pada simulasi untuk memprediksi jumlah konsentrasi sedimen tersuspensi dalam kurun waktu tertentu.

Daerah penelitian ini adalah muara Sungai Pulege dan pantai sekitarnya yang diduga terdapat akumulasi berbagai bahan yang terangkut sepanjang aliran sungai dan 
mengendap di muara sungai sehingga menyebabkan tingkat kekeruhan air menjadi tinggi. Diduga salah satu faktor penyebabnya yaitu tingginya konsentrasi Total Suspended Solid (TSS). Oleh karena itu, maka perlu dilakukan penelitian dengan menggunakan model numerik untuk mengetahui pola penyebaran dan menganalisis aliran sedimen tersuspensi di muara Sungai Pulege Kecamatan Banawa Selatan Kabupaten Donggala.

\section{II.METODE PENELITIAN}

Lokasi penelitian ini adalah di perairan muara Sungai Pulege dan sekitarnya, dalam hal ini di Desa Tanamea, Kecamatan Banawa Selatan Kabupaten Donggala yang secara geografis terletak pada $119^{\circ} 37^{\prime} 05^{\prime \prime}$ - $119^{\circ} 38^{\prime} 05^{\prime \prime}$ BT dan $0^{\circ} 47^{\prime} 45^{\prime \prime}-0^{\circ} 48^{\prime} 48^{\prime \prime}$ LS. Sungai Pulege biasa juga disebut Sungai Tanamea atau Sungai Lembasada dapat dilihat pada gambar 1.

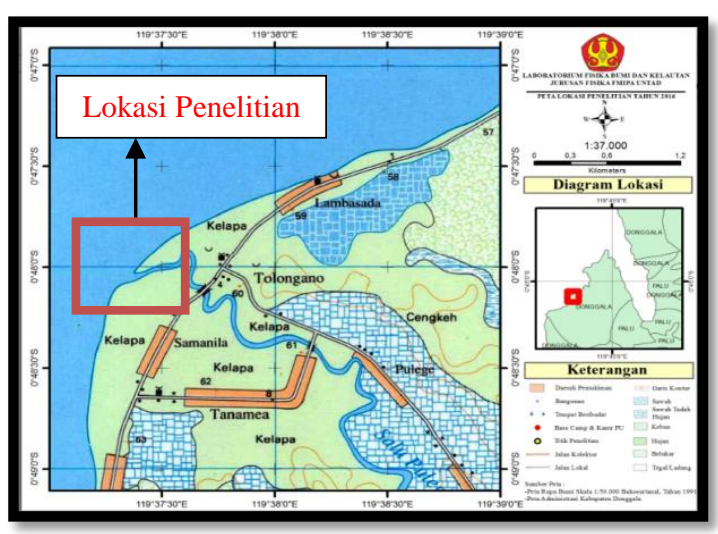

Gambar 1. lokasi penelitian disekitar muara sungai Pulege

Adapun peralatan yang digunakan dalam penelitian ini adalah:

1. Perangkap sedimen digunakan untuk pengambilan sedimen.

2. Botol Nansen, digunakan untuk memperoleh material sedimen layang.

3. Flow meter, digunakan untuk mengukur kecepatan arus.

4. Global Positioning System (GPS), digunakan untuk menentukan posisi (titik koordinat) tempat pengambilan data.

5. Neraca digital digunakan untuk mengukur sedimen.

6. Tidal Staff digunakan untuk mengukur pasang surut dilapangan.

7. Meteran $100 \mathrm{~m}$ digunakan untuk mengukur penampang sungai.

8. Alat tulis menulis. 


\section{HASIL DAN PEMBAHASAN}

\section{Angin Permukaan}

Arah angin di lokasi penelitian dominan bergerak ke Barat Laut dan kecepatan angin dominan sebesar $4.2-6 \mathrm{~m} /$ detik. Untuk mengetahui arah angin dominan, telah digunakan perangkat lunak Oriana yang ditampilkan pada diagram seperti Gambar 2. Data angin yang digunakan adalah data angin pada bulan Nov-Des 2016 dari Stasiun BMKG Palu. Angin merupakan salah satu parameter gaya pembangkit arus pada pemodelan hidrodinamika ini, keluaran dari RMA2 dalam bentuk data kecepatan arus, kemudian dijadikan sebagai data masukan (input) pada SED2D untuk memodelkan sebaran konsentrasi sedimen tersuspensi.

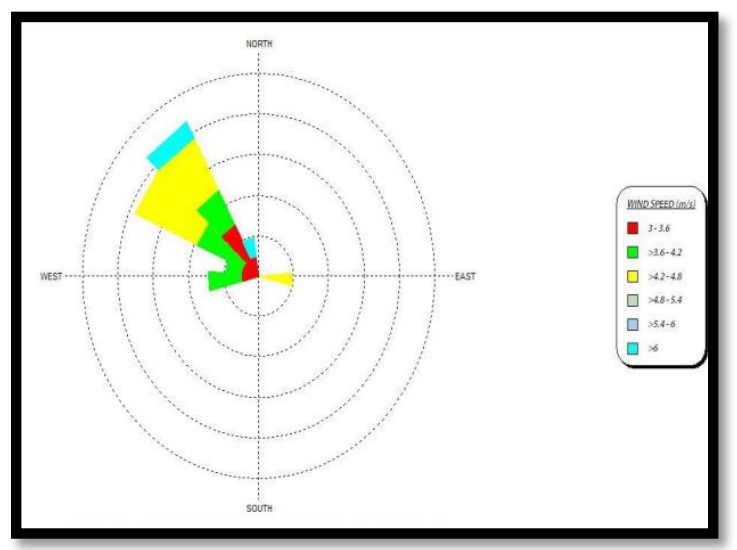

Gambar 2. Diagram Angin Bulan Desember Di Selat Makassar

\section{Gelombang Pasang Surut}

Pasang surut air laut di sekitar Perairan Pantai Desa Tanamea, Kecamatan Banawa Selatan Kabupaten Donggala telah dianalisis menggunakan metode Admiralti. Hasil Analisis setiap komponen dengan menggunakan metode Admiralti menghasilkan nilai amplitudo (A) dan beda fasa $\left(\mathrm{g}^{\circ}\right)$. disajikan pada Tabel 4.1 berikut :

Tabel 1 Nilai-nilai komponen pasang surut di Selat Makassar

\begin{tabular}{|l|c|c|c|c|c|c|c|c|c|c|}
\hline & So & M2 & S2 & N2 & K2 & K1 & O1 & P1 & M4 & M 4 \\
\hline $\mathrm{A}(\mathrm{cm})$ & 55.4 & 29.8 & 45.1 & 4.8 & 10.4 & 39.2 & 35.1 & 12.9 & 3.5 & 15.0 \\
\hline $\mathrm{G}(\mathrm{der})$ & & 210 & 130 & 176 & 130 & 256 & 212 & 256 & 127 & 187 \\
\hline
\end{tabular}

Berdasarkan nilai amplitudo (A) dan beda fasa $\left(\mathrm{g}^{0}\right)$ pada Tabel 1 maka dapat ditentukan tipe gelombang pasang surut dengan menghitung bilangan Formzahl. Dalam perhitungan bilangan Formzahl di butuhkan nilai amplitudo komponen pasut M2, S2, K1 dan O1. Bilangan Formzahl (F) sekitar Perairan Desa Tanamea, Kecamatan Banawa Selatan Kabupaten Donggala dapat di hitung dengan menggunakan persamaan 2.6 sebagai berikut:

$$
\begin{aligned}
\mathrm{F} & =(\mathrm{A}(\mathrm{K} 1)+\mathrm{A}(\mathrm{O} 1) /(\mathrm{A}(\mathrm{M} 2)+(\mathrm{A}(\mathrm{S} 2)) \\
& =(39.2+35.1) /(29.8+45.1) \\
& =74.3 / 74.9
\end{aligned}
$$




$$
=0.99
$$

Besarnya nilai Formzahl di atas menunjukkan bahwa pada Pantai DesaTanamea, Kecamatan Banawa Selatan Kabupaten Donggala memiliki tipe pasut campuran condong harian ganda (mixed tide prevailing semidiurnal) menunjukkan bahwa dalam satu hari terjadi dua kali air pasang dan dua kali air surut, tetapi tinggi dan periodenya berbeda. Dari hasil perhitungan admiralti yang menghasilkan komponen pasang surut maka komponen ini menghasilkan grafik peramalan pasang surut. Gelombang pasang maksimum terjadi pada hari ke-9 dengan nilai amplitudo mencapai $2.1 \mathrm{~m}$ dan surut maksimum mencapai $0.2 \mathrm{~m}$ seperti pada Gambar 3.

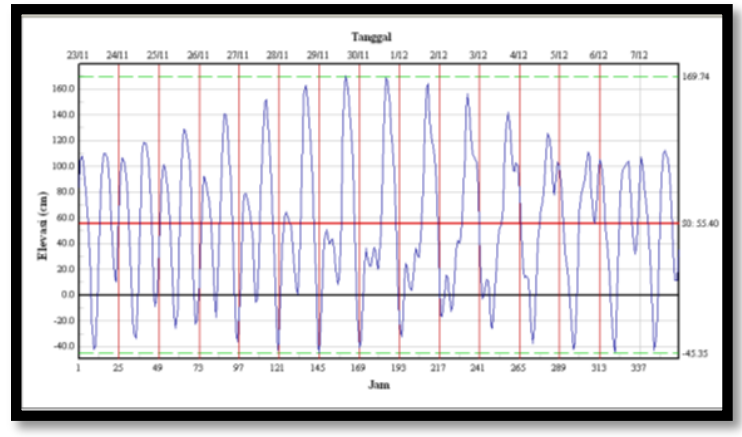

Gambar 3. Grafik Ramalan Pasang Surut

\section{Pola Arus di muara Sungai Pulege}

a. Arus saat gelombang menuju surut purnama
Berdasarkan hasil pemodelan pada Gambar 4, maka diperoleh bahwa arah arus laut disaat kondisi gelombang menuju surut purnama ini cenderung bergerak ke arah timur laut dan hampir sejajar dengan arah garis pantai. Kecepatan arus laut hasil model sekitar $0.14 \mathrm{~m} /$ detik. Arah arus sungai khususnya dimulut sungai menuju ke laut dengan kecepatan sekitar 0.40 $\mathrm{m} /$ detik. Kecepatan arus dimulut sungai pada kondisi ini lebih besar dibandingkan dengan rata-rata kecepatan arus di laut. Kondisi ini diakibatkan oleh pergerakan massa air ketika gelombang menuju surut adalah meninggalkan garis pantai. Situasi massa air tersebut menyebabkan kemiringan muka laut dimulut sungai menjadi meningkat dan menghasilkan arus yang lebih kuat.

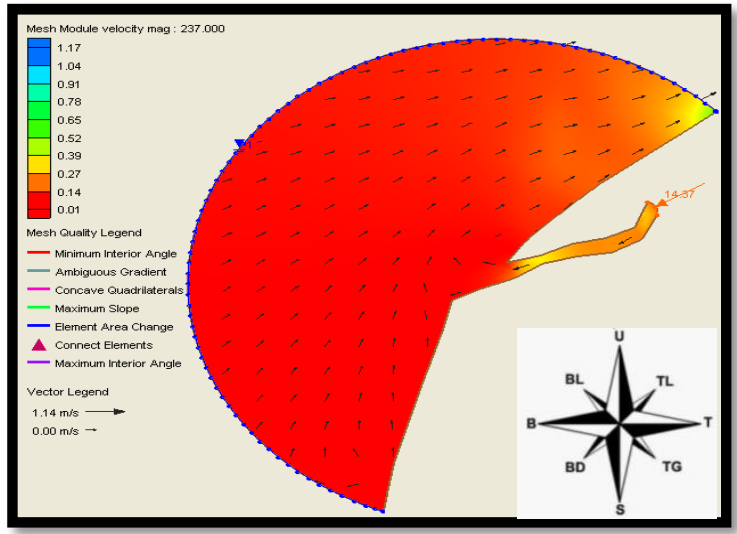

Gambar 4. Pola Arus saat menuju surut purnama (Spring Tide) 
b. Arus di saat gelombang menuju pasang purnama

Gambar 5 menunjukkan pola dan kecepatan arus pada saat air laut menuju pasang pada bulan purnama (spring tide). Kecepatan arus di sungai sekitar 0.41 $\mathrm{m} /$ det sedangkan di muara kecepatan arus melemah sebesar $0.17 \mathrm{~m} /$ det. Arah kecepatan arus atau pergerakan massa air bergerak menuju ke arah selatan ketika air laut ini menuju pasang.

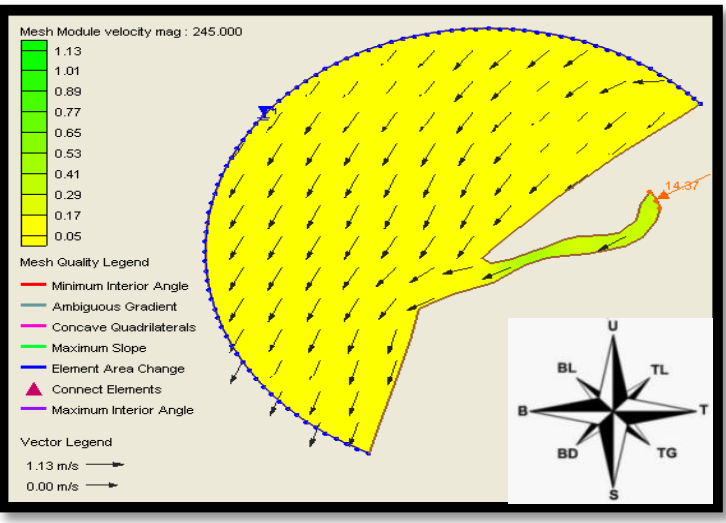

Gambar 5. Simulasi Pola Arus saat menuju pasang purnama (Spring Tide)

\section{Hasil Simulasi Sebaran Sedimen}

\section{Tersuspensi}

\section{Sebaran Konsentrasi Sedimen \\ Tersuspensi Hasil Pengolahan Data Lapangan}

Berdasarkan hasil analisis laboratorium terhadap sampel sedimen tersuspensi yang diperoleh di lapangan, diketahui konsentrasi sedimen tersuspensi di perairan Pantai Tanamea, berkisar antara 0.03-0.40 gr/liter. Khusus di Stasiun I yang terletak di sekitar syarat batas (open boundary) disungai, nilai konsentrasi maksimum hasil pengukuran adalah 0.40 gr/liter. Data hasil pengukuran itu dijadikan sebagai data masukan sedimen melayang ke dalam daerah model. Sedimen melayang ini selanjutnya di angkut oleh arus hasil pemodelan RMA2 sehingga sedimennya terdistribusi keseluruh lokasih penelitian. Konsentrasi sedimen yang terdistribusi pada bagian muara sungai sebesar $0.07 \mathrm{gr} /$ liter. Hal ini dapat di lihat pada Gambar 6.

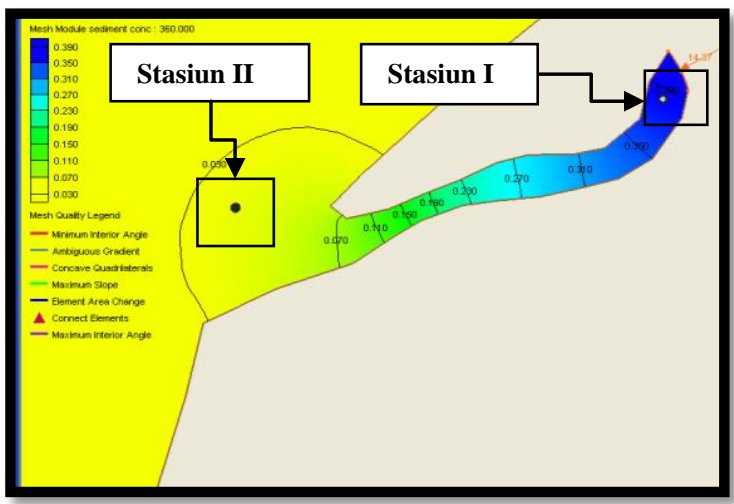

Gambar 6. model konsentrasi sedimen tersuspensi pada stasiun I dan stasiun II saat hari ke 15

Berdasarkan Gambar 6, distribusi sedimen pada hari ke 15 terjadi pengurangan konsentrasinya saat menuju mulut sungai. Di stasiun II, konsentrasi sedimen melayang berkurang menjadi 0.03 gr/liter 
atau hanya sekitar 13\% dibandingkan konsentrasi di Stasiun I. Grafik sebaran sedimen tersuspensi berdasarkan hasil model dari SED2D

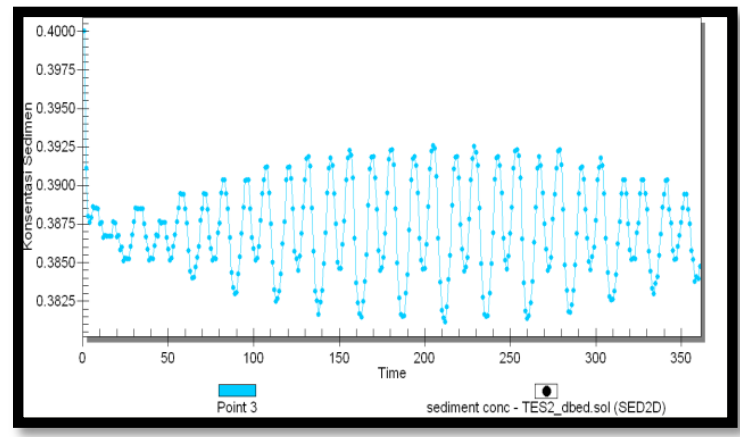

Gambar 7. Grafik Sebaran Sedimen Tersuspensi Pada Stasiun I Saat Menuju Pasang (Spring Tide)

Berdasarkan dari hasil model SED2D pada stasiun I, Gambar 7 menunjukkan bahwa sebaran sedimen tersuspensi awal 0.40 gram/liter. Jumlah konsentrasi sedimen mulai berkurang pada time step ke 4-50 disebabkan karena kecepatan debit aliran sungai mengalami penurunan sehingga konsentrasi sedimen di stasiun tersebut mengecil. Konsentrasi sedimen mulai bertambah pada saat time step ke 60-335 terutama pada time step ke 205 mengalami peningkatan hingga mencapai 0.39 gram/liter, meningkatnya konsentrasi sedimen pada time step tersebut disebabkan oleh kecepatan debit aliran sungai yang tinggi.

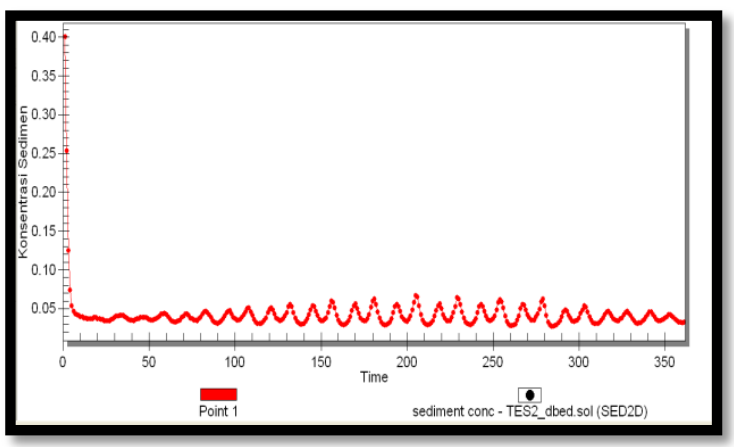

Gambar 8. Grafik Sebaran Sedimen Tersuspensi pada Stasiun II Saat Menuju Surut (Spring Tide)

Gambar 8 menunjukkan bahwa sebaran sedimen tersuspensi pada stasiun II dengan jumlah kosentrasi sedimen awal 0.40 gr/liter, berkurangnya angkutan sedimen hingga $0.05 \mathrm{gr} / \mathrm{liter}$ pada saat time step ke 5-100 di pengaruhi oleh kecepatan arus yang rendah sehingga sedimen mengalami pengendapan di dasar sungai dan tidak mengalami proses sedimentasi (Aditya Eka Purnama dkk, 2015). Konsentrasi sedimen mengalami peningkatan pada time step ke 150-280 dengan jumlah konsentrasi berkisar $0.08 \mathrm{gr} / \mathrm{liter}$ disebabkan karena sedimen yang terendap di dasar sungai mengalami pengadukan sedimen, yang diakibatkan oleh kecepatan arus yang tinggi sehingga kandungan sedimen tersuspensi menjadi tinggi. Kosentrasi sedimennya mulai berkurang kembali hingga 0.03 gr/liter pada time step 285-350. 


\section{Pembahasan}

\section{Sebaran Konsentrasi Sedimen Tersuspensi}

Berdasarkan hasil analisis laboratorium, konsentrasi sedimen tersuspensi disekitar Perairan Tanah Mea, Kecamatan Banawa Selatan Kabupaten Donggala berkisar antara $0.03-0.40 \mathrm{gr} /$ liter pada kondisi surut menuju pasang purnama. sungai Pulege merupakan sumber pasokan sedimen menuju laut. Angkutan sedimen tersuspensi di sungai berhubungan erat dengan erosi permukaan tanah oleh hujan, run-off dan aktivitas manusia di daerah hulu sungai. Air hujan dapat mengikis tanah mengakibatkan longsoran tanah yang kemudian diangkut menuju muara sungai. Proses tersebut berpengaruh terhadap jumlah konsentrasi angkutan sedimen di mulut sungai. Muara sungai adalah bagian dari sungai yang berhubungan langsung dengan laut. Sedimen tersuspensi dari Sungai Pulege akan terangkut menuju perairan sekitar Tanamea. Konsentrasi dan jarak jangkauan sebaran sedimen tersuspensi di laut dipengaruhi oleh besarnya suatu debit sungai, konsentrasi sedimen tersuspensi dari sungai, koefisien difusi, dan arus laut akan menggerakkan massa air beserta sedimen tersuspensi ketika angkutan sedimen tersuspensi sampai di laut. Konsentrasi sedimen tersuspensi di mulut sungai tinggi dan konsentrasinya semakin kecil dengan nilai terendah ke arah muara sungai menuju ke laut (Gambar 4.5). Berdasarkan hasil yang telah di dapatkan maka bagian mulut sungai yang mendekati muara tidak terjadi pendangkalan disebabkan oleh tingkat konsentrasi sedimen yang berasal dari sungai lebih besar di bandingkan yang menyebar menuju laut dan tidak dapat mengganggu keseimbangan ekosistem, biota laut sekitaran Pantai Tanamea.

\section{Simulasi Pola Arus}

Pembuatan model simulasi arus menggunakan modul RMA2 pada software SMS 8.1. Hasil pola arus di Perairan Pantai TanaMea mengikuti gerakan pasang dan surut air laut. Hasil model tersebut diperkuat oleh grafik data arus hasil pengukuran di lapangan selama 15 hari yang diolah menggunakan metode Atmiralti untuk memperoleh bilangan Formzahl dan hasilnya menunjukkan bahwa arus yang paling dominan adalah arus pasut. Perairan Pantai Tanamea mempunyai pola pasut campuran condong 
harian ganda. Angin dominan bergerak ke arah barat laut (Gambar 4.2), kecepatan angin dominan sebesar 4.2-6 m/detik. Kecepatan arus hasil pengukuran maksimum di lapangan sebesar $0.22 \mathrm{~m} / \mathrm{det}$ sedangkan untuk kecepatan arus hasil model maksimum sebesar $0.29 \mathrm{~m} / \mathrm{det}$. Hasil verifikasi data hasil model dengan data saat pengukuran adalah $13.50 \%$. Hasil model ini menunjukkan bahwa pada Spring Tide yang terjadi pada akhir bulan November, arus cenderung bergerak ke arah barat daya dan selatan. Hal ini disebabkan karena awal bulan Desember musim sudah berganti ke monsun Barat, disini arah angin cenderung bergerak kearah barat daya.

\section{Simulasi Sebaran Konsentrasi Sedimen Tersuspensi}

Model simulasi konsentrasi sedimen tersuspensi dibuat menggunakan modul numerik 2 dimensi SED2D pada software SMS 8.1. Inputan model sebaran konsentrasi sedimen tersuspensi pada muara Sungai Pulege yaitu debit sungai sebesar 14.37 m³/detik, dan nilai konsentrasi sedimen di sungai yaitu 0,40 gr/liter yang dijadikan nilai acuan untuk penyebaran sedimen tersuspensi ketika menuju muara sungai dan perairan selat makassar sekitarnya. Hal ini dikarenakan dibagian sungai dianggap sebagai media pemasok sedimen tersuspensi di Perairan selat makassar. Proses simulasi model memperhatikan arah angin pada muara Sungai Pulege, angin cenderung bergerak ke arah barat laut. Kecepatan dan arah angin juga dijadikan sebagai inputan pembuatan model. Hasil model menunjukkan bahwa konsentrasi sedimen tersuspensi di perairan pantai tanamea yang berasal dari sungai pulege yang cukup besar, sehingga debit sungai lebih dominan dari arus pasut di pantai tanamea ini. Arah konsentrasi dipengaruhi dan mengikuti arah angin dan arah arus yang ada. Debit sungai mempengaruhi pasokan sedimen tersuspensi dari darat dan dipengaruhi oleh musim, curah hujan menentukan besar suatu debit. Jumlah curah hujan kecil menyebabkan debit aliran kecil, sehingga material sedimen melayang yang diangkut sedikit, sedangkan jika curah hujan besar, nilai debit aliran besar sehingga jumlah material sedimen melayang yang diangkut pun banyak. Musim berpengaruh terhadap jumlah curah hujan yang mengalir ke sungai dan mempengaruhi debit aliran. 
Mulyanto (2007) menjelaskan bahwa curah hujan dan debit sungai mempunyai hubungan, semakin tinggi suatu curah hujan maka run-off dan debit sungai juga semakin besar. Hujan jangka pendek juga akan menghasilkan run-off dan akan berpengaruh juga dengan debit sungai. Studi mengenai sebaran konsentrasi sedimen tersuspensi sangat penting untuk mengetahui potensi terjadinya sedimentasi di suatu wilayah perairan. Faktor oseanografi juga berpengaruh secara langsung terhadap proses sebaran sedimen tersuspensi yang terjadi di laut. Sifat-sifat sedimen juga sangat penting di dalam mempelajari proses erosi dan sedimentasi.

\section{KESIMPULAN}

Adapun kesimpulan dari penelitian ini adalah :

1. Pola arus di perairan sungai Pulege di dominasi oleh arah yang menuju ke barat laut. Arus yang tejadi pada saat menuju surut purnama dengan nilai kecepatan $0.14 \mathrm{~m} /$ det pada sekitaran perairan Pantai Tanamea dan kecepatan arus yang berada di mulut sungai sebesar $0.40 \mathrm{~m} /$ det. Kecepatan arus saat menuju pasang purnama dengan nilai maksimum sebesar $0.41 \mathrm{~m} /$ det dan nilai kecepatan minimumnya yang berada di sekitar muara sebesar $0.17 \mathrm{~m} /$ det.

2. Berdasarkan hasil simulasi menggunakan model SMS 8.1 (Surfacewater Modeling system), pada modul SED2D telah dihasilkan model sebaran sedimen dimuara Sungai Pulege yang diakibatkan oleh meningkatnya nilai kosentrasi sedimen yang berada di sungai mencapai 0.40 gram/liter, sehinnga sedimennya terdistribusi ke seluruh lokasi penelitian.

3. Simulasi model sebaran konsentrasi sedimen tersuspensi pada kondisi Spring Tide, arah persebarannya mengikuti arah angin dan pergerakan arus pasut. Arah penyebarannya dominan ke arah barat laut. Debit sungai lebih dominan di Perairan sungai pulege dan sekitarnya karena nilai debit sungai yaitu $14.37 \mathrm{~m}^{3} /$ det lebih besar dari pada arus pasut yaitu $0.27 \mathrm{~m} / \mathrm{det}$, ketika terjadi pasang pada kondisi Spring Tide, pergerakan arus di mulut sungai tidak bisa merubah arah kecepatannya karena kecepatan aliran sungai dan debit sungai yang tinggi. Debit sungai membawa partikel sedimen tersuspensi dari bagian mulut sungai menuju muara dan berdasarkan 
hasil simulasi sebaran sedimen maka konsentrasi sedimen di muara sungai adalah $0.07 \mathrm{gr} / \mathrm{liter}$.

\section{DAFTAR PUSTAKA}

Atmodjo, W., (2011), Studi Penyebaran Sedimen Tersuspensi Di Muara Sungai Porong Kabupaten Pasuruan, Buletin Oseanografi Marina, Vol. 1, Hal. 60-81.

Aditya, E.P., Hariadi, Sidd hi Sap hi, S., (2015), Pengaruh Arus, Pasang Surut Dan Debit Sungai terhadap distribusi sedimen tersuspensi di perairan muara sungai ciberes, cerebon, http://ejournal s1.undip.ac.id/index.php/jose, Vol. 4, No 1, Hal. 74-84.

Damayanti, H.O., dan Hernawan, U., (2014), Pola Penyebaran Sedimen Tersuspensi Berdasarkan Analisis Debit Maksimum dan Minimum di Muara Sungai Porong Kabupaten Pasuruan, Jurnal Widyariset, Vol. 17 No. 2, Hal. 291-302.

Mulyanto, (H.R. 2007). Sungai Fungsi dan Sifat-Sifatnya. Penerbit Graha Ilmu, Yogyakarta.

Soewarno. (1991). Pengukuran dan Pengolahan Data Aliran Sungai. Bandung: Penerbit Nova.

Sinaga, A. T., A. Satriadi, Hariyadi, \& F. Novico. (2013). Pola Sebaran Sedimen Tersuspensi Berdasarkan Model Pola Arus Pasang Surut di Perairan Teluk Balikpapan, Kalimantan Timur. Jurnal Ilmu Kelautan UNDIP, Vol 2:329 - 336.
Triatmodjo, B., 1999, Teknik Pantai, Beta Offset, Yogyakarta.

\section{UCAPAN TERIMA KASIH}

Penulis berterima kasih kepada Kepala kepala Laboratorium Fisika Kebumian dan Oseonografi, Laboratorium Kimia FMIPA Universitas tadulako dan pembimbing 1 dan pemimbing II, Terima kasih atas segala macam bantuan demi terselesaikannya penelitian ini. 